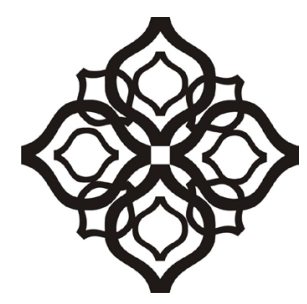

Shirkah

Journal of Economics and Business 


\section{Shirkah}

Journal of Economics and Business

Vol. 2, No. 2, May-August 2017

ISSN: 2503-4235 (p); 2503-4243 (e)

\section{Editor in Chief}

Sri Walyoto

\section{Editorial Boards}

Abu Umar Faruq Ahmad, UBD School of Business and Economics, Brunei Darussalam

Amelia Fauzia,

Asia Research Institute, National University of Singapore, Singapore

Cedomir Nestorovic,

ESSEC Business School Asia Pacific, Singapore

Dwi Condro Triono,

Faculty of Islamic Economics and Business, IAIN Surakarta, Indonesia

Fahmy Radhi,

Faculty of Economics and Business Universitas Gadjah Mada, Yogyakarta,

Indonesia

Hasan Basri,

Syiah Kuala University, Aceh, Indonesia

Johan Fischer,

Department of Social Sciences and Business Roskilde University, Denmark

Masudul Alam Choudhury,

Postgraduate Program in Islamic Economics and Finance, Trisakti University,

Jakarta, Indonesia and the College of Economics and Political Science (CEPS) in

Sultan Qaboos University (SQU), Oman

M. Falik Isbah,

School of Humanities and Social Science, University of New South Wales, Australia M. Ishaq Bhatti,

La Trobe Business School Department of Economics and Finance La Trobe

University, Australia

Najib Kailani,

Pascasarjana, Universitas Islam Negeri (UIN) Sunan Kalijaga, Yogyakarta, Indonesia 
Nunung Nurul Hidayah,

Aston Business School, Aston University, Birmingham, United Kingdom

Shaikh M Ghazanfar,

Departement of Economics, University of Idaho, Russian Federation

\section{Managing Editors}

Fitri Wulandari

Jasanta Perangin-angin

\section{Assistant to Editor}

M. Endy Saputro

M. Zainal Anwar

Supriyanto

Shirkah Journal of Economics and Business is a peer-reviewed journal published three times a year (January-April, May-August and September-December) by Faculty of Islamic Economics and Business, Institut Agama Islam Negeri (IAIN/ State Institute for Islamic Studies) Surakarta Central Java, Indonesia. The main objective of Shirkah is to offer an academic space of exchange ideas and initiate the increase number of qualified article produced by postgraduate students, practitioners and academicians.

\section{Editorial Office}

Ruang Jurnal Shirkah

Ground Floor, West Gate,

Faculty of Islamic Economics and Business

IAIN Surakarta

Jln. Pandawa No. 1, Kartasura, Sukoharjo, Jawa Tengah Kode Pos. 57168

Phone (+62271) 781516 Fax: (+62271)782336

E-mail: shirkahiainsurakarta@gmail.com

Website: http://shirkah.or.id/ 


\section{Shirkah}

Journal of Economics and Business

Vol. 2, No. 2, May-August 2017

ISSN: 2503-4235 (p); 2503-4243 (e)

\section{Table of Contents}

\section{Articles}

Shairil Izwan Taasim

Ramali Yusoff

An Instrument Developing Cashless in Malaysia

Aam S. Rusydiana

Irman Firmansyah

Efficiency versus Maqasid Sharia Index An Application on Indonesia

Islamic Bank

Azhar Ibrahim

The Call for Islamic Economics Shades of Contestation

Warsono

Deferred Tax Assets and Deferred Tax Expense Against Tax Planning Profit Management

Lisdawati Arifin

Earning on Response Coefficient in Automobile and Go Public

Companies

Farihatul Qamariyah

Waroeng Steak: Spritual Company in the Context of Post-Capitalism 


\title{
An Instrument Developing Cashless in Malaysia
}

\author{
Shairil Izwan Taasim \\ Open University Malaysia \\ cheril.com@gmail.com \\ Ramali Yusoff \\ University Malaysia Sabah
}

\begin{abstract}
This study aims to apply the technology assessment (TA) model on e-banking perceptions in the context of Malaysia, which involves aspects of supply and demand, and increasing the cashless concept in the country. A sample of 470 respondents were randomly selected from high density state capitals and major cities, through the convenience sampling method. Respondents were requested to complete a questionnaire developed from the basic model by forming UTAUT constructs, including quality, skills, transaction costs, user satisfaction, role of service providers (banks), and the influence of environment. Based on the results obtained, the model suggests that transaction costs, as direct costs by service providers, have a significant impact on the overall assessment of the performance of retail e-banking. Data analysis was performed using structured equation modeling (SEM), with the use of AMOS V22 as a method of trajectory analysis.
\end{abstract}

Keywords: technology, SEM, performance, e-banking.

\section{Introduction}

E-Banking use was initiated July, 2001 in Malaysia. At this time, Bank Negara Malaysia provided approval to commercial banks to launch e-banking as a platform for consumer transactions. The e-banking revolution, according to Sharma (2011), is a tool for banks to attract and retain customers (Rajendran, 2017). It is related to the competition among commercial banks, where consumers have the ability to become bankers, 
since diversity in e-banking for consumers is beyond conventional banking boundaries (Sabharwal, 2017; Wang, 2017; Sachdeva, 2017). Martin et al. (2013) and Lee et al. (2010) performed empirical research to identify positive and negative factors to accelerate e-banking, but their model was restricted and focused research-based on acceptance. Several studies in the related literature aim identify factors that can accelerate e-banking as a consumer transaction method, in order to decrease the number of users using cash as an instrument (Siddik, 2016). The objective of this research is to identify instruments between demand and supply factors in our model, which would help to accelerate cashless platforms such as e-banking in Malaysia.

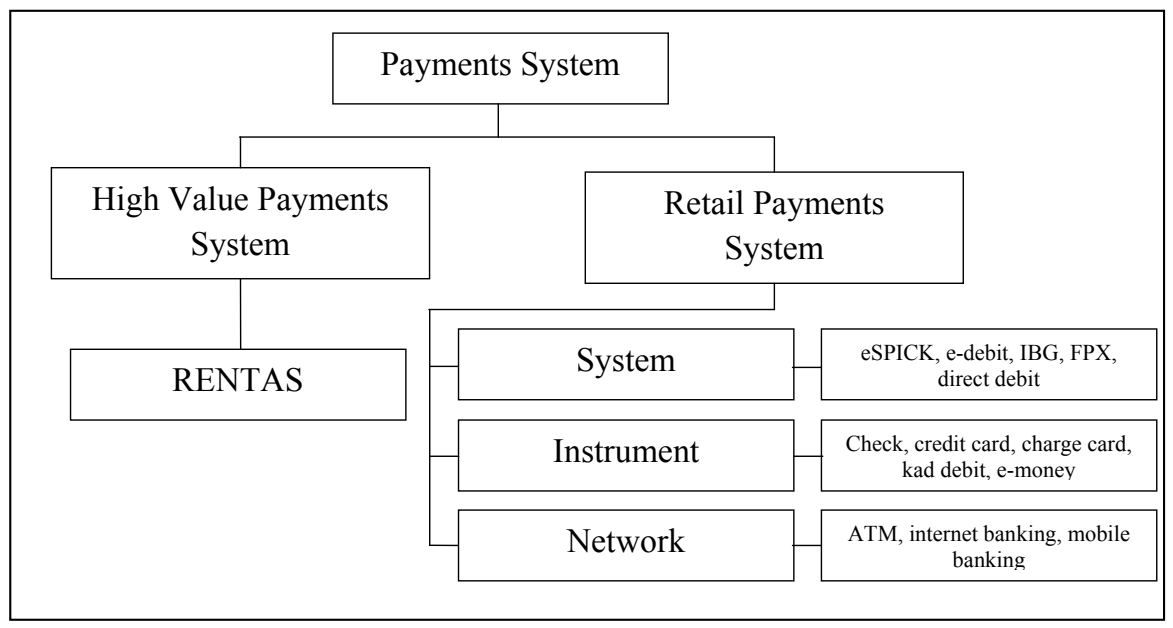

Figure 1: Payments System in Malaysia

Source : Bank Negara Malaysia, 2013

In Malaysia, payment systems are classified under two methods: RENTAS and Retail Payment Systems. This study focuses on retail payments systems in networks as instruments. ATMs, internet banking and mobile banking are transaction methods that do not involve cash. The modern industry, by contrast, is marked by the invention and use of new technology, and e-finance is one such tool. 


\section{Discourse on E-Finance Platforms}

E-finance platforms have become increasingly popular once research started to focus on consumer acceptance toward this new method of finance over conventional methods. Davis (1989) used to identify consumer acceptance using the Technology Acceptance Model (TAM), and extended it to TAM-3. TAM is more focused on consumer perceived usefulness and perceived ease of use, but it is not related to the system functions of e-banking. Lee et al. (2010) revealed that there was less acceptance in Taiwan because skilled computer users had a high correlation to the increased number of acceptance users, mainly due the lack security in e-banking. The integration of the TAM had an impact on inter-relationship between consumers and service providers based on previous research (Kolodinsky et al., 2004; Venkatesh et al., 2003).

Table 2

Percentage of Non-Cash Methods in Malaysia

\begin{tabular}{|r|c|c|c|c|c|}
\hline & $\mathbf{2 0 0 8}$ & $\mathbf{2 0 0 9}$ & $\mathbf{2 0 1 0}$ & $\mathbf{2 0 1 1}$ & $\mathbf{2 0 1 2}$ \\
\hline Cek & 15.9 & 14.9 & 14.4 & 12.5 & 11.1 \\
\hline Instrument of Payment & 74.1 & 73.5 & 70.8 & 70.9 & 71.8 \\
\hline Credit Card & 20 & 20.1 & 20.5 & 19.4 & 17.7 \\
\hline Charge card & 0.4 & 0.4 & 0.3 & 0.2 & 0.2 \\
\hline Debit Card & 0.8 & 0.8 & 1.3 & 1.5 & 2.0 \\
\hline e-money & 52.8 & 52.2 & 48.7 & 49.7 & 51.9 \\
\hline Network of Payment & 7.0 & 8.2 & 11.1 & 12.7 & 13.1 \\
\hline Internet banking & 5.3 & 6.3 & 8.4 & 10.0 & 10.2 \\
\hline Mobile banking & - & - & - & 0.1 & 0.4 \\
\hline ATM & 1.6 & 1.8 & 2.7 & 2.6 & 2.5 \\
\hline
\end{tabular}

Source: Bank Negara Malaysia, 2013

Poon (2008) found that of $89 \%$ respondents agreed to the price for an internet connection, as computers in Malaysia are affordable. In Malaysia, the cost for a computer that connects consumers to bankers is inexpensive. 
In 2013, BNM agreed to decrease the cost of interbank Giro from RM2.00 to RM0.10 cents for each transaction (BNM, 2013). Zinman (2009) mentioned that consumer have the choice to use cash, card or online transfer, based on acceptance, safety, cost of time and usefulness. The number of users of non-cash methods has increased yearly from 2008 and 2012, as show in Table2. However, volatility for non-cash methods in Malaysia are much more stable yearly for ATM and e-banking, even though there is restricted access internet in urban areas. Users of conventional methods are 99\% compared to the Philippines (96\%), Indonesia (84\%) and Thailand (78\%) (BNM, 2013). Based on the vision of BNM to increase cashless methods in Malaysia, the finance sector launched a platform in 2010, expected to be used from 2011 until 2020.

Courchane et al. (2002) stated that e-banking changed because of competition, laws, and the environment (Zulkhibri, 2016; Alawneh, 2016). Increasing internet users is one of the reasons why consumers changed to online methods (Alimolaei, 2016). In Malaysia, there was a 356.8\% increase in e-banking between 2000-2010 (BNM, 2013). As stated in Table 2, the percentage of users of e-banking shows an increase compared to other methods of payment. Sathye (1999) stated that access to the internet is one factor that influences the acceptance towards e-banking (Jovovic, 2016; Maroofi, 2015).

\section{Gathering Data}

The study used a quantitative method to develop the UTAUT model, which involves supply and demand data. A sampling method by Cohen (1992) was adopted. Respondents who have participated in this research are from the capital city for each state in Malaysia, since previous studies (Murillo et al., 2010) mention that the geography factor plays an important role in justifying user acceptance towards e-banking. Yuen and Yeow (2009) mention that a capital city has more prospect in e-banking 
compared to rural areas. Five indicators as an instruments were used in this study, to identify the factors that impact users to change to cashless banking methods in Malaysia. The indicators come from the UTAUT model by Venkatesh et al. (2003), with adjustment as recommended by Lee et al. (2010) and Qingfei et al. (2008). Quality, skills, environment, banks, and cost of transaction were the five indicators applied in the proposed model. Yahya et al. (2012) developed and used the UTAUT as a platform technology acceptance model to investigate consumer behavior.

Data for this study were collected from a total of 800 questionnaires that were distributed across Malaysia in March, 2015.The feedback rate was $58.75 \%$, which corresponds to cumulative 470 respondents. Cohen (1992) based their model on the $G^{*}$ Power analysis sample, which fulfils a minimum requirements: effect size $=0.15$ (medium), statistical inference $=0.95$, Delta $=8.39$, and critical $\mathrm{t}=6.72$. Income plays an important role in this research. We found that the percentage of respondents with a monthly salary of less than RM2,000 was 51.4\%; RM2,000 - RM4,000 was $39.2 \%$, and more RM4,000 was $9.4 \%$.

\section{Structural Equation Model (SEM)}

CFA-SEM was used in this research to find the relations between instruments and performance of cashless banking methods in Malaysia. Timothy (2011) suggested that a suitable model for SEM sample sizes should be 100-150; while Schumacker and Lomax (2010) mentioned that the $\mathrm{N}$ statistic $>200$ is suitable for SEM. The variance for each instrument is as follows: quality (62\%), cost (56.3\%), bank (54.8\%), skills (48.8\%) and environment $(52.1 \%)$. In path analysis conducted by SEM, our model must be justified to have fulfilled the minimum requirements from previous research (Hair et al. 2010; Zainuddin 2014). 
Table 3: Analysis Confirmatory Model

\begin{tabular}{|l|c|c|c|l|}
\hline Categories Index & Index & $\begin{array}{c}\text { Level of } \\
\text { Acceptance }\end{array}$ & Value & Comments \\
\hline Absolute Index & Chisq & $\mathrm{p}>0.05$ & 0.000 & Level requirements achieved \\
\cline { 2 - 5 } & RMSEA & $<0.08$ & 0.076 & Level requirements achieved \\
\hline Incremental Fit & CFI & $>0.90$ & 0.935 & Level requirements achieved \\
\cline { 2 - 5 } & TLI & $\approx 1$ & 0.922 & Level requirements achieved \\
\cline { 2 - 5 } & NFI & $\approx 1$ & 0.914 & Level requirements achieved \\
\hline Parsimonious fit & CMIN/df & $<5$ & 3.725 & Level requirements achieved \\
\hline
\end{tabular}

The theoretical model should have a measurement validity, based on three types of indices. Zainuddin (2014) mentioned that there is no restriction to justify which index is suitable to validate a model. However, Hair et al. (2010) provides choices on which index can be used to justify the model. The confirmatory model in Table 3 shows that the minimum requirements were achieved, based on three (3) categories of indices. The absolute index: Chi-square is 0.00 and RMSEA is less than 0.08 , with a value of 0.076 . This index is used for validity measurement in structural models based, as mentioned by Hair et al. (2010). The analyses shows that the value of TLI (0.922) and NFI (0.914) achieved over 0.9, and are thus at suitable value (Hair et al., 2010). The findings reveal that CMIN/df in parsimonious fit achieved a value less than 5 (3.725). 


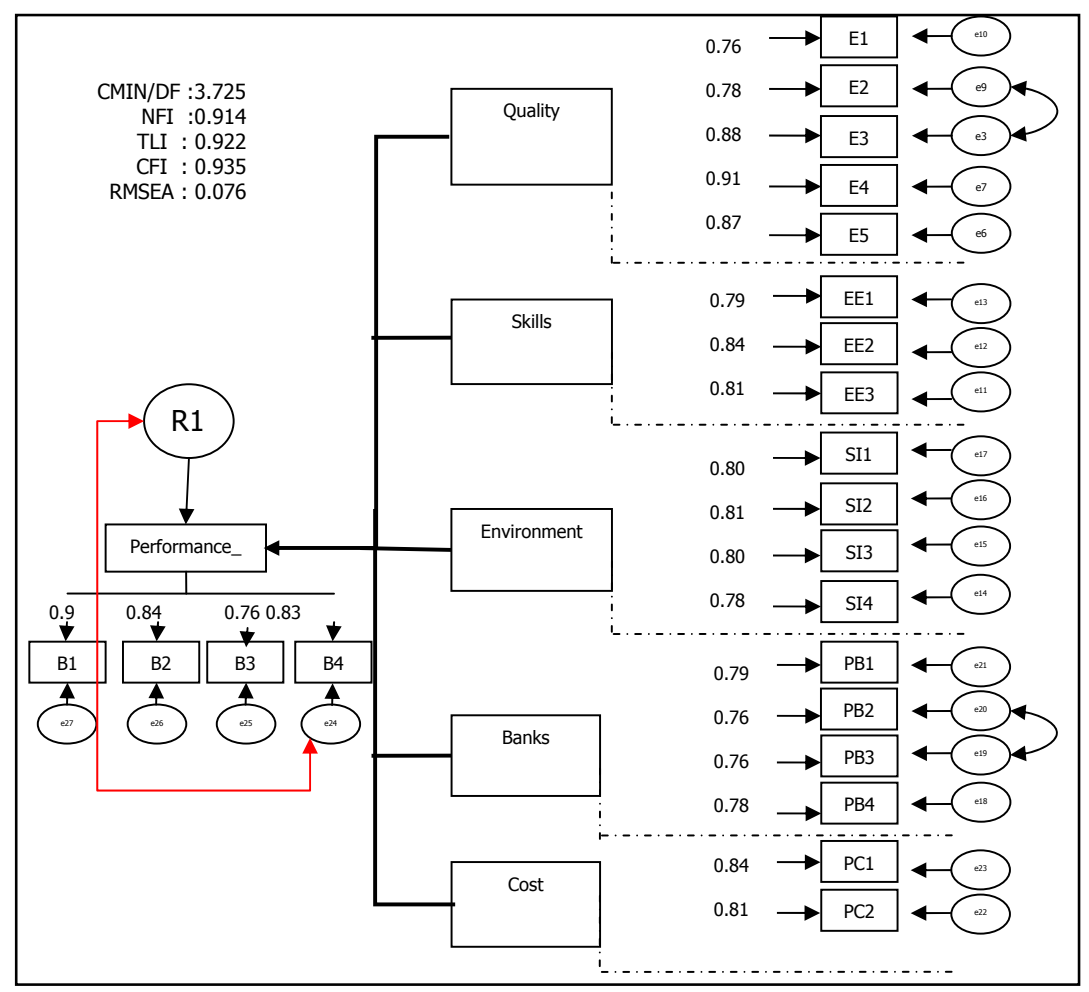

\section{Figure 4: Result Path Analysis.}

Figure 4 shows the model after adjustment to give higher reliability and validity, as recommended by Hair et al. (2010). Results of the path analysis confirm the loading to be more than 0.5 . This shows a causal relationship between the factor analysis and the dependent variable. Results from the SEM analysis show only the cost factor as significant and having an impact to increase cashless banking methods in Malaysia. Our model is based on Zainuddin (2014), who removed one or two items that correlate in a new model and increase the value of RMSEA. In this research, the correlation between factors are e-24 and R1, e9-e8 and e20 and e21. The results are shown in Figure 4. 
Table 5: Result Hypothesis Testing

\begin{tabular}{|c|c|c|c|c|c|}
\hline Construct & $\begin{array}{c}\text { Unstandardized } \\
\text { Path } \\
\text { Coefficients }(\beta)\end{array}$ & $\begin{array}{c}\text { Critical } \\
\text { Value (CR) }\end{array}$ & $\begin{array}{c}\text { Regression } \\
\text { Weights }\end{array}$ & P-Value & Hypothesis \\
\hline Quality & 0.122 & $\begin{array}{c}1.29 \\
(<1.96)\end{array}$ & 0.077 & 0.19 & Rejected \\
\hline Skills & 0.010 & $\begin{array}{c}0.07 \\
(<1.96)\end{array}$ & 0.060 & 0.95 & Rejected \\
\hline Environment & 0.073 & $\begin{array}{c}0.172 \\
(<1.96)\end{array}$ & 0.042 & 0.863 & Rejected \\
\hline Banks & 0.298 & $\begin{array}{c}0.869 \\
(<1.96)\end{array}$ & 0.176 & 0.385 & Rejected \\
\hline Cost & 0.539 & $\begin{array}{c}2.516 \\
(>1.96)\end{array}$ & 0.326 & 0.012 & Accepted \\
\hline
\end{tabular}

Table 5 shows the analysis results where the path analysis shows that the cost instrument directly impacts increasing cashless methods, $(\beta=0.539$, $\mathrm{p}<0.05$; CR $>1.96$ ).

i. Quality $(\beta=0.122, \mathrm{p}>0.05 ; \mathrm{CR}<1.96)$,

ii. Skills $(\beta=0.010, \mathrm{p}>0.05 ; \mathrm{CR}<1.96)$,

iii. Environment $(\beta=0.073, \mathrm{p}>0.05 ; \mathrm{CR}<1.96)$,

iv. $\operatorname{Banks}(\beta=0.298, \mathrm{p}>0.05$; $\mathrm{CR}<1.96)$.

The correlation for each construct is higher than expected, where the value is more than 0.70: quality and skills (0.813); quality and bank (0.736); cost and quality (0.762); skills and environment (0.819); skills and bank (0.821); cost and skills (0.800); cost and environment (0.897); and cost and bank (0.815). Chua (2014) mentioned a correlation of (r) 0.91 to 1.0 is very high, 0.71 to 0.90 is high and 0.6 and below is weak and needed adjustment in the model. In this research, the costs instrument, such as direct costs, which refers to each consumer transaction, shows a positive relationship to develop cashless methods in Malaysia. 


\section{Conclusion}

The study also confirmed that consumers emphasize direct costs versus indirect costs as on-line financial activities featured management costs compared to the conventional methods, in which indirect costs are typically higher and are ignored by respondents. In conclusion, the creation of an innovative society with direct implications for the existence of more economical costs for consumers is based on the direct costs of e-retail banking activities. Cost in this research focused on direct costs for each consumer transaction, after users are active in using e-banking systems. We conclude that, the cost instrument is the most likely to increase cashless methods in Malaysia, although Bank Negara Malaysia has announced that cost transactions have decreased to more than 95\%, but this still has an impact on consumers. As a suggestion to improve cashless methods in Malaysia, banks should not charge for direct costs.

Overall, the study describes the model variance (81\%) in the evaluation of the performance of e-banking. This study has important theoretical and practical contributions that describe the performance assessment of retail banking technology in the context of Malaysia. Therefore, the assessment of technology is able to describe the performance levels established by users in terms of the strengths and weaknesses of the country in planning for the creation of an innovative society. 


\section{References}

Alawneh, A., Diabat, M.A. (2016). Measurement of E-Banking Services Quality: An Empirical Experimentation in Jordan. International Journal of Business Information System 23 (4), 522-541.

Alimolaei, S. (2016). An Intelligent System for User Behavior Detection in Internet Banking. 4th Iranian Joint Congress on Fuzzy and Intelligent Systems, CFIS 20157391642.

Bank Negara Malaysia. (2013). Laporan Kestabilan Kewangan dan Sistem Pembayaran.

Chua, Y. P. (2014). Ujian Regresi, Analisis Faktor dan Analisis SEM. Mc Graw Hill. Ed.2.

Cohen, J. (1992). A power primer. Psychological Bulletin, 112(1), 155-159.

Courchane, M., Nickerson, D., dan Sullivan, R. (2002). Investment in internet banking as a real option: Theory and tests. Journal of Multinational Financial Management. 12(4-5):347-363.

Davis, F.D. (1989). Perceived Usefulness, Perceived Ease of Use and User acceptance of Information Technology. MIS Quarterly. 13(3): 319340 .

Hair, J. F., Black, W. C., Babin, B. J. dan Anderson, R.E. (2010). Multivariate Data Analysis. A Global Perspective. Prentice Hall.

Jovovic, R., Lekic, E., Jovovic, M. (2016). Monitoring the Quality of Services in Electronic Banking. Journal of Central Banking Theory and Practice 5 (3). 99-119.

Kolodinsky, J., Hogarth, J., dan Hilgert, M. (2004). The Adoption of Electronic Banking Technologies by US consumer. International Journal of Bank Marketing. 22 (4): 238-259.

Lee K. W., Tsai, M. T., dan Corazon, M. (2010). From Marketplace to Market Space : Investigating the Consumer Switch to Online Banking. Journal Electronic Commerce Research and Applications. 10 (1): 115-125. 
Maroofi, F., Kalhori, K. (2015). Value and Risk in Business to Business E-Banking. Trends, Prospects, and Challenges in Asian E-Governance, 325-351.

Martin, C., Oliveira, T., dan Popovic, A. (2013). Understanding the internet banking adoption: A unified theory of acceptance and use of technology and perceived risk application. International Journal of Information Management. Article In Press.

Murillo, R. H., Llobet, G., dan Fuentes, R. (2010). Strategic Online Banking Adoption. Journal of Banking \& Finance. 34:1650-1663.

Poon, W. C. 2008. Users Adoption of E-Banking Services: The Malaysia Perspective. Journal of Business \& Industrial Marketing. 23(1): 59-69.

Qingfei, M., Shaobo, J., dan Gang, Q. (2008). Mobile Commerce User Acceptance Study in China: A Revised UTAUT Model. Tsinghua Science and Technology. 13(3): 257-264.

Rajendran, R.P., Suresh, J. (2017). Customer Satisfaction Index as a Performance Evaluation Metric: A Study on Indian E-Banking Industry. International Journal of Business 22 (3), 251-274.

Sabharwal, M. (2017). Multi-modal Biometric Authentication and Secure Transaction Operation Framework for E-Banking. International Journal of Business Data Communications and Networking 13 (1), $102-$ 116.

Sachdeva, K., Kumar, P.S. (2017). Impact of E-Banking on the Performance of Commercial Banks in India: A Panel Data Approach. International Journal of Applied Business and Economic Research 15 (9), 55-67.

Sathye, M. (1999). Adoption of Internet Banking by Australian Consumer: An Empirical Investigation. International Journal of Bank. 17(7):324334.

Schumacker, R. E., dan Lomax, R. G. (2010). Structural Equation Modelling. Routledge Taylor \& Francis Group, New York. 
Sharma, H. (2011). Bankers Perspectives on E-Banking. National Journal of System and Information Technology. 1(1): 71-85.

Siddik, M.N.A., Sun, G., Kabiraj, S., Shanmugan, J., YanJuan, C. (2016). Impact of E-Banking on Performance of Banks in a Developing Economy: Empirical Evidence from Bangladesh. Journal of Business Economics and Management 17 (6), 1066-1080.

Timothy, T. (2011). Factors Influencing Teachers' Intention to Use Technology: Model Development and Test. Journal Computers \& Education. 57:2432-2440.

Venkatesh, K., Morris., Davis, G. B., dan Davis, F. D. (2003). User Acceptance of Information Technology: Toward A Unified View. MIS Quarterly. 27(3): 425-478.

Wang, M., Cho, S., Denton, T. (2017). The Impact of Personalization and Compability with Past Experience on E-Banking Usage. International Journal of Bank Marketing 35 (1), 45-55.

Yahya, M., Nadzar, F., dan Rahman, B. A. (2012). Examining User Acceptance of E-Syariah Portal Among Syariah Users in Malaysia. Procedia Social and Behavioral Sciences. 67: 349-359.

Yuen, Y., dan Yeow, P. H. (2009). User Acceptance of Internet Banking Service in Malaysia. In J. Cordeiro, S. Hammoudi and J. Filipe (Eds.), Web Information Systems and Technologies. 18: 295-306).

Zainudin, A. (2014). A Handbook on SEM for Academicians and Practitioners. MPWS Rich Resources.

Zinman, J. (2009). Debit or credit?. Journal of Banking and Finance. 33: 358-366.

Zulkhibri, M., Rani, M.S.A. (2016). Term Spread, Inflation and Economic Growth in Emerging Markets: Evidence from Malaysia. Review of Accounting and Finance 15 (3), 372-392. 


\section{Shirkah Author Guidelines}

Shirkah currently offers two routes to submit manuscripts. We highly recommend to submit the articles which are made using OJS (Open Journal System). Feel free register as author soon through visiting http:// shirkah.or.id/index.php/home/user/register. The authors may directly send their manuscripts, along with their resume, to shirkahiainsurakarta@ gmail.com. Please prepare your manuscripts, using following guidelines:

1. Manuscript must be written in English. Submitted articles should not have been published or be under review for publication with another journal.

2. Manuscript's length is about $15-20$ pages, typed in one-half spaced on A4-paper size.

3. Manuscript must include an $150-200$ word abstract and keywords.

4. Manuscript must be arranged as follows: Title, Name of Author, E-mail address, Abstract, Keywords, Introduction (including method if any), Discussion, Conclusion, References.

5. Manuscript's titles not more than ten words.

6. Manuscript must be submitted in Microsoft Word or RTF.

7. Arabic words should be transliterated according to the style of International Journal of Middle Eastern Studies.

8. Manuscript references are preferably derived from the up-to-date references.

9. The author's resume should be submitted separately, consisting of at least full name, institutional address, phone number, areas of studies, and recent publications (if any).

10. Shirkab use APA Style 6th edition (2010) as reference format writing. We suggest the use of a reference manager software such as Mendeley, Zotero, and Endnote at templating the citation style. APA Style to be used is as follows: 


\section{Book with single author}

Swann, G. M. Peter. (2014). The Economics of Innovation an Introduction. Cheltenhum \& Northampton: Edward Elgar.

in-text citation: (Swann, 2014)

\section{Articles in reference books}

Alatas, S. F. (2006). Islam and the Science of Economics in Abu Rabi', I.M. The Blackwell Companion to Contemporary Islamic Thought. USA: Willey-Blackwell (pp. 587-606).

in text citation: (Alatas, 2006)

\section{E-Book}

Hackett, Rosalind (2007). "Religous Dimentions of War and Peace: Introduction.” Dalam Gerrie ter Haar dan Yoshio Tsuruoka (Ed.), Religion and Society: An Agenda for the 21st Century (h. 3-6). Retrieved from http:// brill.nl.

in text citation: (Hackett, 2006)

\section{Master's thesis, from a commercial database}

McNieI, D. S. (2006). Meaning through narrative: A personal narrative discussing growing up with an alcoholic mother (Master's thesis). Available from ProQuest Dissertations and Theses database. (UMI No. 1434728)

in text citation: (Mc Niel, 2006)

\section{Doctoral dissertation, from an institutional database}

Adams, R. J. (1973). Building a foundation for evaluation of instruction in higher education and continuing education (Doctoral dissertation). Retrieved from http://www.ohiolink.edu/etd/

in text citation: (Adams, 1973) 


\section{Doctoral dissertation, from the web}

Bruckman, A. (1997). MOOSE Crossing: Construction, community, and learning in a networked virtual world for kids (Doctoral dissertation, Massachusetts Institute of Technology). Retrieved from http:/www-static. cc.gatech.edu/--asb/thesis/

in text citation: (Bruckman, 1997)

\section{Journal article with No DOI}

Bourkhis, K., and Nabi, M. S. (2013). Islamic and conventional banks' soundness during the 2007-2008 financial crisis. Journal Metrics, 22(2), 68-77.

in-text citation: (Bourkhis \& Nabi, 2013).

\section{Journal article with DOI}

Ichwan, M. (2012). The Local Politics Of Orthodoxy: The Majelis Ulama Indonesia in the Post-New Order Banten. Journal Of Indonesian Islam, 6(1), 166-194. doi:http://dx.doi.org/10.15642/JIIS.2012.6.1.166-194

In text citation : (Ichwan, 2012)

\section{Abstract as citation}

Hasan, N. (2012). Islamist Party, Electoral Politics And Da'wah Mobilization Among Youth : The Prosperous Justice Party (PKS) in Indonesia. Journal of Indonesian Islam, 6(1), 17-47. Abstract from http:// jiis.uinsby.ac.id/index.php/jiis/article/view/97

in text citation : (Hasan, 2012)

\section{Mass media article}

Sahal, Akhmad (2014, March 2). Kiai Sahal dan Realisme Fikih.Tempo Magazine, p. 120.

in text citation : (Sahal, 2014) 


\section{Research report}

Fisher, B. S., Cullen, F. T., \& Turner, M. G. (2000). The Sexual Victimization of College Women. Research Report.

in text citation : (Fisher, Cullen, Turner, 2000)

\section{Monograph}

Routray, Bibhu Prasad (2013), National Security Decision-Making in India (RSIS Monograph No. 27). Singapura: Rajaratnam School of International Studies.

in text citation : (Routray, 2013)

\section{Proceeding article}

Sudibyakto, Hizbaron, D.R., \& Jati, R (Ed.) (2009), Proceeding International Seminar Disaster Theory, Research and Policy. International seminar held by Sekolah Pascasarjana, Universitas Gajahmada, Yogyakarta, 8-9 Desember 2009.

in text citation : (sudibyakto and Jati, 2009)

\section{Paper conference/seminar/symposium}

Janutama, Herman Sinung (2011). "Kraton dan Hubungan Antar Agama." Paper presented in Seminar Kraton dan Panatagama held by Center for the Study of Islam and Social Transformation (CISForm), Yogyakarta, 17 November.

in text citation :(Janutama, 2011)

\section{Online article in web}

Shiva, (2006, February). Bioethics: A Third World Issue. Native-web. Diperoleh dari http://www.nativeweb.org/ pages/legal/shiva.html

in text citation : (Shiva, 2006) 


\section{Online research report}

Kessy, S. S. A., \& Urio, F M. (2006). The contribution of microfinance institutions to poverty reduction in Tanzania (Research Report No. 06.3). Retrieved from Research on Poverty Alleviation website: http://www. repoa.or.tz /documents_storage/Publications/Reports/06.3_Kessy_and_ Urio.pcif

in text citation : (kessy and urion, 2006)

\section{Holy book}

Qur an, $2(25)$

In text citation : (Q. al-Baqarah 2:25).

\section{Encyclopaedia}

Graycar, Adam (1992). Social Welfare Policy. Dalam Mary Hawkesworth dan Maurice Kogan (Ed.), Encyclopedia of Government and Politics (Vol. 1). London: Routledge.

in text citation : (Graycar, 1992)

\section{Interview}

Sultan Hamengkubuwono X (interview, 2011, April 19)

in text citation: (Hamengkubuwono, 2011)

\section{Documentary film}

Steijlen, Fridus (2008). A Day in the Life of Indonesia [documentary film, 58 minutes]. Leiden: KITLV Press.

in text citation : (Steijlen, 2008) 
Vol. 2 No. 2, May - August 2017 